\title{
Performance of methods for estimation of table beet water requirement in Alagoas
}

\author{
Daniella P. dos Santos ${ }^{1}$, Célia S. dos Santos ${ }^{1}$, Leiliane M. da Silva ${ }^{2}$, \\ Márcio A. L. dos Santos² \& Cícero G. dos Santos ${ }^{2}$ \\ ${ }^{1}$ Universidade Federal Rural de Pernambuco/Departamento de Engenharia Agrícola. Recife, PE. E-mail: daniellapsantos@hotmail.com - ORCID: \\ 0000-0002-4450-0141; celia@agro.eng.br - ORCID: 0000-0001-9784-3001 (Corresponding author) \\ ${ }^{2}$ Universidade Federal de Alagoas/Campus Arapiraca/Departamento de Agronomia. Arapiraca, AL. E-mail: leiliane.agro@gmail.com - ORCID: \\ 0000-0003-0989-0794; mal.santo@hotmail.com - ORCID: 0000-0001-5216-4443; cgomes_al@hotmail.com - ORCID: 0000-0002-2264-6772
}

Key words:

lysimetry irrigation management Beta vulgaris L.

\begin{abstract}
A B S T R A C T
Optimization of water use in agriculture is fundamental, particularly in regions where water scarcity is intense, requiring the adoption of technologies that promote increased irrigation efficiency. The objective of this study was to evaluate evapotranspiration models and to estimate the crop coefficients of beet grown in a drainage lysimeter in the Agreste region of Alagoas. The experiment was conducted at the Campus of the Federal University of Alagoas - UFAL, in the municipality of Arapiraca, AL, between March and April 2014. Crop evapotranspiration (ETc) was estimated in drainage lysimeters and reference evapotranspiration (ETo) by Penman-Monteith-FAO 56 and Hargreaves-Samani methods. The Hargreaves-Samani method presented a good performance index for ETo estimation compared with the Penman-Monteith-FAO method, indicating that it is adequate for the study area. Beet ETc showed a cumulative demand of $202.11 \mathrm{~mm}$ for a cumulative reference evapotranspiration of $152.00 \mathrm{~mm}$. Kc values determined using the Penman-Monteith-FAO 56 and Hargreaves-Samani methods were overestimated, in comparison to the Kc values of the FAO-56 standard method. With the obtained results, it is possible to correct the equations of the methods for the region, allowing for adequate irrigation management.
\end{abstract}

\section{Palavras-chave:}

lisimetria manejo de irrigação

Beta vulgaris L.

\section{Desempenho de métodos de estimativa da necessidade hídrica da beterraba de mesa em Alagoas}

\begin{abstract}
R E S U M O
A otimização do uso da água na agricultura é fundamental, em particular em regiões onde a escassez hídrica é intensa, exigindo a adoção de tecnologias que promovam aumento da eficiência de irrigação. Assim, objetivou-se avaliar modelos de evapotranspiração e estimar os coeficientes de cultivo da beterraba cultivada em lisímetro de drenagem na região agreste de Alagoas. O experimento foi conduzido na área experimental do Campus da Universidade Federal de Alagoas-UFAL, no município de Arapiraca, AL, entre março e abril de 2014. A evapotranspiração da cultura (ETc) foi estimada em lisímetros de drenagem e a evapotranspiração de referência (ETo) pelos métodos de Penman-Monteith-FAO 56 e Hargreaves-Samani. O método de Hargreaves-Samani apresentou ótimo índice de desempenho da estimativa de ETo quando comparado com o método de Penman-MonteithFAO 56 indicando ser adequado para a área de estudo. A ETc da beterraba apresentou uma demanda acumulada de 202,11 mm, para uma evapotranspiração de referência acumulada de 152,00 mm. Os Kc's determinados utilizando os métodos de Penman-Monteith-FAO 56 e Hargreaves-Samani apresentaram superestimativa, quando comparados com os valores de Kc's do método padrão da FAO 56. Com os resultados obtidos é possível fazer correções nas equações dos métodos para a região, possibilitando adequado manejo de irrigação.
\end{abstract}




\section{INTRODUCTION}

Native to Europe, beet (Beta vulgaris L.) is an herbaceous, dicotyledon plant belonging to the Chenopodiaceae family. It is a vegetable with great economic importance in Brazil and one of the top ten vegetable crops cultivated (Sediyama et al., 2011). For being commercially exploited, the study on beet is of great importance, especially regarding its water requirements (Lacerda \& Turco, 2015).

For adequate irrigation management and rational use of water, it is necessary to know the crop coefficient (Kc). $\mathrm{Kc}$ determination requires the application of some method to estimate or measure ETo and the knowledge on crop evapotranspiration (ETc) (Miranda et al., 2016).

Studies comparing reference evapotranspiration (ETo) estimation methods in comparison to the Penman-Monteith method parameterized by FAO have been conducted in different regions of Brazil to evaluate the efficiency of indirect methods (Cavalcante Júnior et al., 2011; Borges Júnior et al., 2012; Silva et al., 2014b; Tanaka et al., 2016).

Various studies report the application of water demand and crop coefficients (Kc) of vegetables, such as Silva et al. (2014a), Santana et al. (2016) and Santos et al. (2016a).

In the specific case of the Arapiraca-Alagoas region, evapotranspiration and Kc data of various crops do not exist, notably beet. Therefore, considering the importance of this crop and absence of information on its water management, it is essential to implement an irrigation management with rationalization of water resources. Hence, the objective was to evaluate the performance of evapotranspiration models and estimate the coefficients of the beet crop grown in drainage lysimeters for the Agreste region of Alagoas.

\section{Material AND Methods}

The experiment was carried out in the experimental area of the Arapiraca Campus of the Federal University of Alagoas $\left(9^{\circ}\right.$ $45^{\prime}$ S, 36 39' W, $264 \mathrm{~m}$ ), under field conditions, in the months of March and April 2014. The climate of the region, according to the classification of Köppen (1948), is As tropical. The rainy season starts in May and continues until early August, with mean annual rainfall of $854 \mathrm{~mm}$, and the months from May to July are the rainiest ones, whereas months from September to December are the driest ones (Xavier \& Dornellas, 2010).

The soil of the experimental area is classified as dystrophic Red Yellow Latosol (EMBRAPA, 2013). For its physical characterization, disturbed and undisturbed samples were collected in the $0-20 \mathrm{~cm}$ layer to determine the following physical attributes: texture (hydrometer method), soil bulk density (Ds - volumetric ring method), soil particle density (Dp - volumetric flask method), moisture at field capacity (FC) and moisture at permanent wilting point (PWP) (EMBRAPA, 2006), presented in Table 1.
For the experiment, a bed was built $(3.5 \times 1.0 \mathrm{~m})$ with total area of $3.5 \mathrm{~m}^{2}$, in which three drainage lysimeters were installed. The bed was composed of three plant rows, with spacing of $0.20 \mathrm{~m}$ between plants and $0.30 \mathrm{~m}$ between rows, and a population of 51 plants (Figure 1).

Three circular drainage lysimeters were used, built with a polyethylene pot. Each lysimeter had diameter of $0.30 \mathrm{~m}$ and depth of $0.30 \mathrm{~m}$, obtaining an exposure area of approximately $0.070 \mathrm{~m}^{2}$. The lysimeters were installed in soil pits $(0.35 \mathrm{x} 0.50 \mathrm{~m})$, taking care to separate the soil into three $0.10 \mathrm{~m}$ layers.

The lysimeters were installed in the second row, corresponding to the central row of the area, so that plants maintained the same spacing both along the lysimeter row and for side rows. Each lysimeter was composed of one plant. Beet seedlings, cv. Early Wonder tall top, were transplanted at 33 days after sowing (DAS)

The drainage system of the lysimeters consisted of a 20-mm-diameter PVC pipe connected to a $3.85 \mathrm{~L}$ pot, in an observation well positioned in a slight slope along the direction of drain, in which the percolated excess of water was collected and measured.

To avoid the passage of sediments and possible clogging in the piping of the drainage system, before filling the lysimeter, a flexible Nylon screen was placed in the internal outlet of the drains, followed by a 0.20 -m-thick layer of crushed stone at the bottom of the pot. The lysimeters were filled with soil, according to the original profiles of the area.

Irrigations were applied by dripping, trying to increase soil moisture to the field capacity condition, and irrigation management was conducted based on water balance and crop evapotranspiration.

Water collected in the drains was daily measured using a $1 \mathrm{~L}$ graduated cylinder, starting always at $9 \mathrm{~h}$ and ending at $10 \mathrm{~h}$ a.m. The water used came from the local supply and its salinity corresponded to $0.12 \mathrm{dS} \mathrm{m}^{-1}$, also used by Santos et al. (2016b).

Solar radiation, air temperature and relative humidity, wind speed, atmospheric pressure and rainfall data were collected using an automatic weather station (Thies Clima Model) and were used to estimate reference evapotranspiration (ETo) by the methods Penman-Monteith-FAO-56, with parametrization proposed by Allen et al. (1998), and Hargreaves-Samani (Pereira et al., 1997).

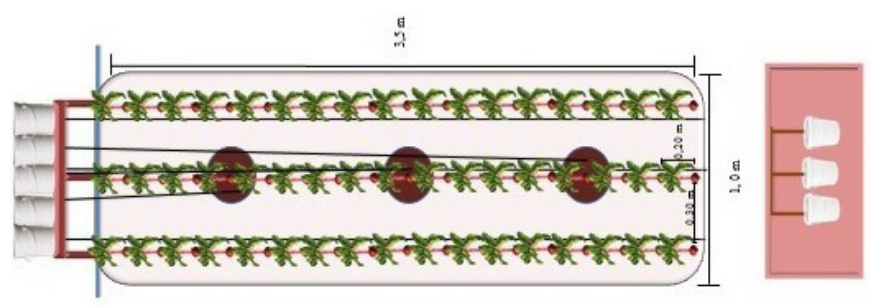

Figure 1. Distribution of beet rows and installation of lysimeters

Table 1. Physical characteristics of the soil profile in the experimental area of the Arapiraca Campus, in the 0-20 $\mathrm{cm}$ layer

\begin{tabular}{|c|c|c|c|c|c|c|c|c|c|}
\hline \multirow{2}{*}{\multicolumn{2}{|c|}{ Depth $(\mathbf{c m})$}} & Sand & Clay & Silt & Ds & Dp & $\mathrm{FC}$ & PWP & \multirow{2}{*}{ Textural class } \\
\hline & & & $\%$ & & \multicolumn{2}{|c|}{$\mathrm{g} \mathrm{cm}^{-3}$} & \multicolumn{2}{|c|}{$\mathrm{cm}^{-3}$} & \\
\hline Lysimeters & $0-20$ & 82.56 & 10.39 & 7.05 & 1.33 & 2.72 & 0.30 & 0.20 & Loamy sand \\
\hline
\end{tabular}

Ds - Soil bulk density; Dp - Soil particle density; FC - Field capacity; PWP - Permanent wilting point 
ETc was obtained by direct measurements in the lysimetric system according to Aboukhaled et al. (1982), who established the following equation (Eq. 1):

$$
\mathrm{ETc}=\frac{(\mathrm{P}+\mathrm{I}-\mathrm{D})}{\mathrm{A}}
$$

where:

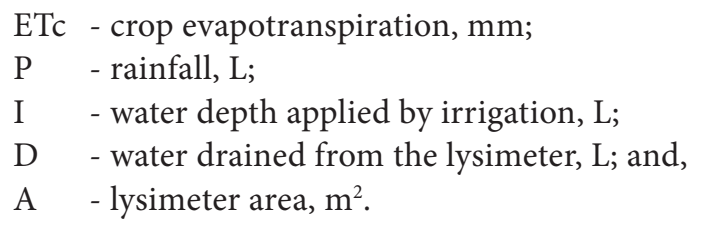

ETo and ETc values were used to determine the crop coefficients (Eq. 2):

$$
\mathrm{Kc}=\frac{\mathrm{ETc}}{(\mathrm{ETo})}
$$

where:

Kc - crop coefficient, dimensionless;

ETc - crop evapotranspiration, $\mathrm{mm} \mathrm{d}^{-1}$; and,

ETo - reference evapotranspiration, $\mathrm{mm} \mathrm{d}^{-1}$.

Crop cycle according to Doorenbos \& Pruitt (1977) comprehends the following phenological stages:

I) Initial stage, 0 to 7 days;

II) Growth stage, 8 to 23 days; and,

III) Final stage, 24 to 30 days.

ETo data resulting from the application of the presented method were subjected to statistical analysis. Model accuracy was evaluated using the coefficient of determination $\left(\mathrm{R}^{2}\right)$ of the linear regression between ETo estimated by certain empirical method and by the Penman-Monteith-FAO-56 method (standard).

The performance of each method was evaluated using the performance index proposed by Camargo \& Sentelhas (1997) (c), who suggest as statistical indices Pearson's correlation coefficient ( $r$ ) for accuracy and index of agreement of Willmott et al. (1985) (d).

The $\mathrm{d}$ index varies from 0 to 1 , and the value 1 indicates perfect exactness between estimated data and those adopted as standard, while 0 indicates no agreement between the analyzed values.

Performance index was quantitively and qualitatively evaluated according to the classification of Camargo \& Sentelhas (1997). Errors generated by the estimates were quantified using the parameters employed by Back (2008).

\section{Results AND Discussion}

For the climatological variables used in the evapotranspiration estimation in the studied area (Table 2), relative humidity showed the highest deviation in relation to the mean, whereas solar radiation exhibited the lowest standard deviation, and rainfall showed the highest coefficient of determination.

Regarding the " $\mathrm{d}$ " and " $\mathrm{c}$ " indices, which evaluate agreement and performance, respectively, relative to the ETo values estimated by the proposed method (Figure 2A), the Hargreaves-Samani method showed $\mathrm{r}=0.86$ when compared with the standard Penman-Monteith-FAO 56 method, considered as with very good agreement and classified as "Optimal" for the performance criterion, for daily estimation.

Table 2. Statistical analysis of the climatological variables used in evapotranspiration estimation in Arapiraca-AL, Brazil

\begin{tabular}{lcccc}
\hline Statistical parameters & $\mathbf{P}(\mathbf{m m})$ & WS $\left(\mathbf{m ~ s}^{-1}\right)$ & $\mathbf{T}\left({ }^{\mathbf{0}} \mathbf{C}\right)$ & $\mathbf{R H}(\%)$ \\
Mean & 2.43 & 2.17 & 26.00 & 78.71 \\
Maximum & 20.20 & 6.40 & 34.80 & 96.00 \\
Minimum & 0 & 0 & 20.30 & 3.00 \\
Standard deviation & 4.50 & 1.54 & 3.12 & 9.90 \\
Coefficient of variation & 1.85 & 0.71 & 0.12 & 0.00 \\
\hline
\end{tabular}

Values obtained along the experimental period (Mar to Apr 2015); P - Rainfall; WS - Wind speed; T - Temperature; RH - Relative humidity; Rs - Solar radiation

A.

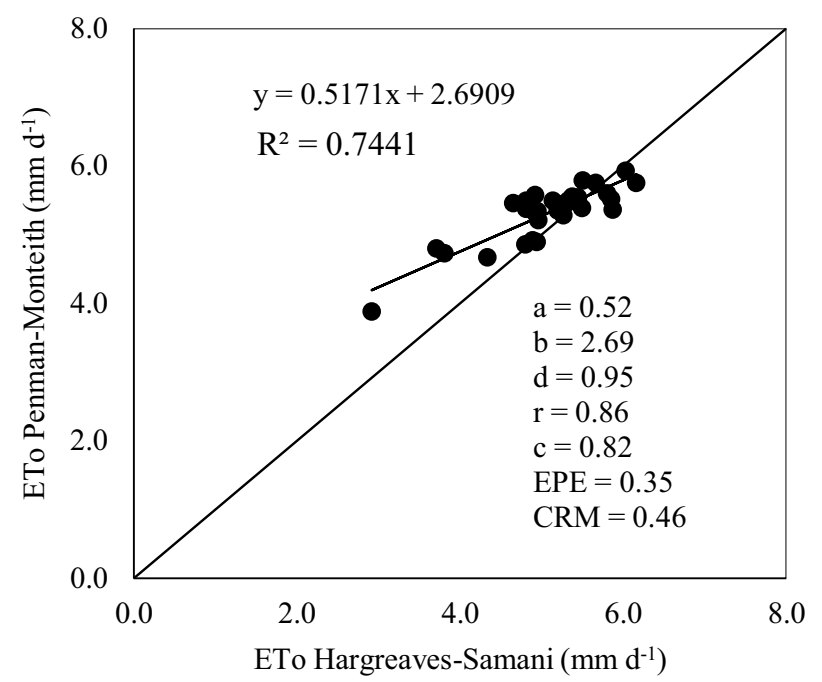

B.

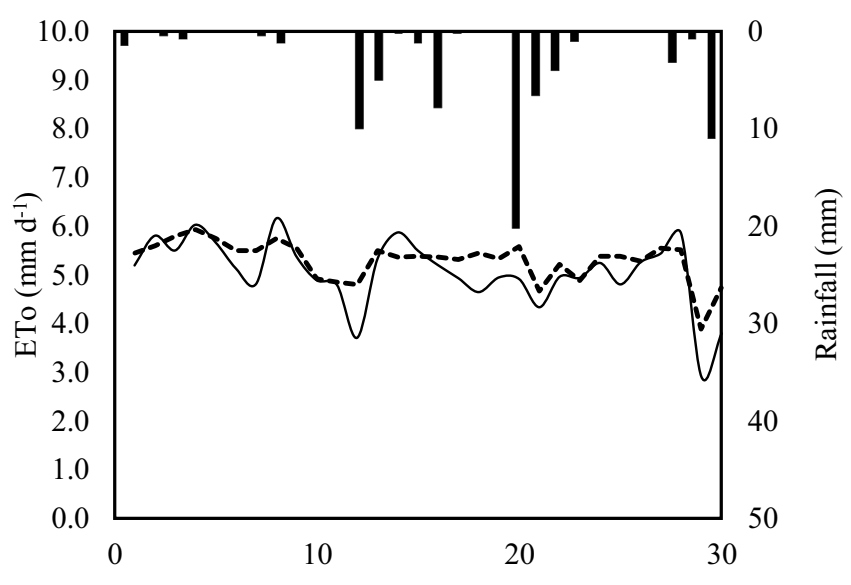

Days after transplantation (DAT)

Rainfall

Figure 2. Analysis of daily correlation and temporal series of ETo by Penman-Monteith (A) and Hargreaves-Samani (B) 


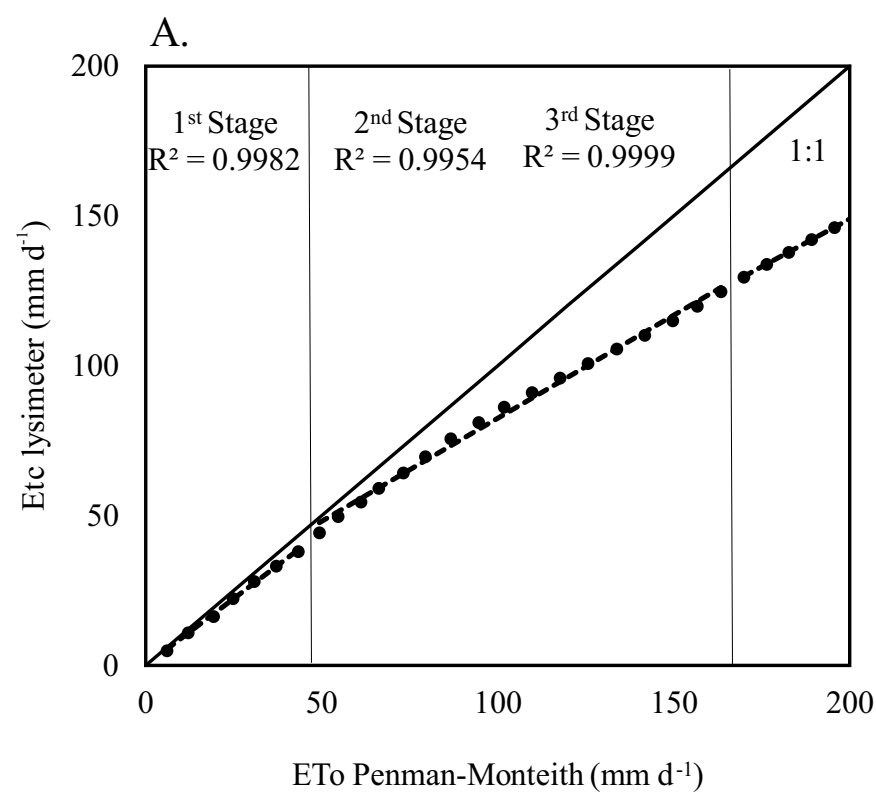

B.
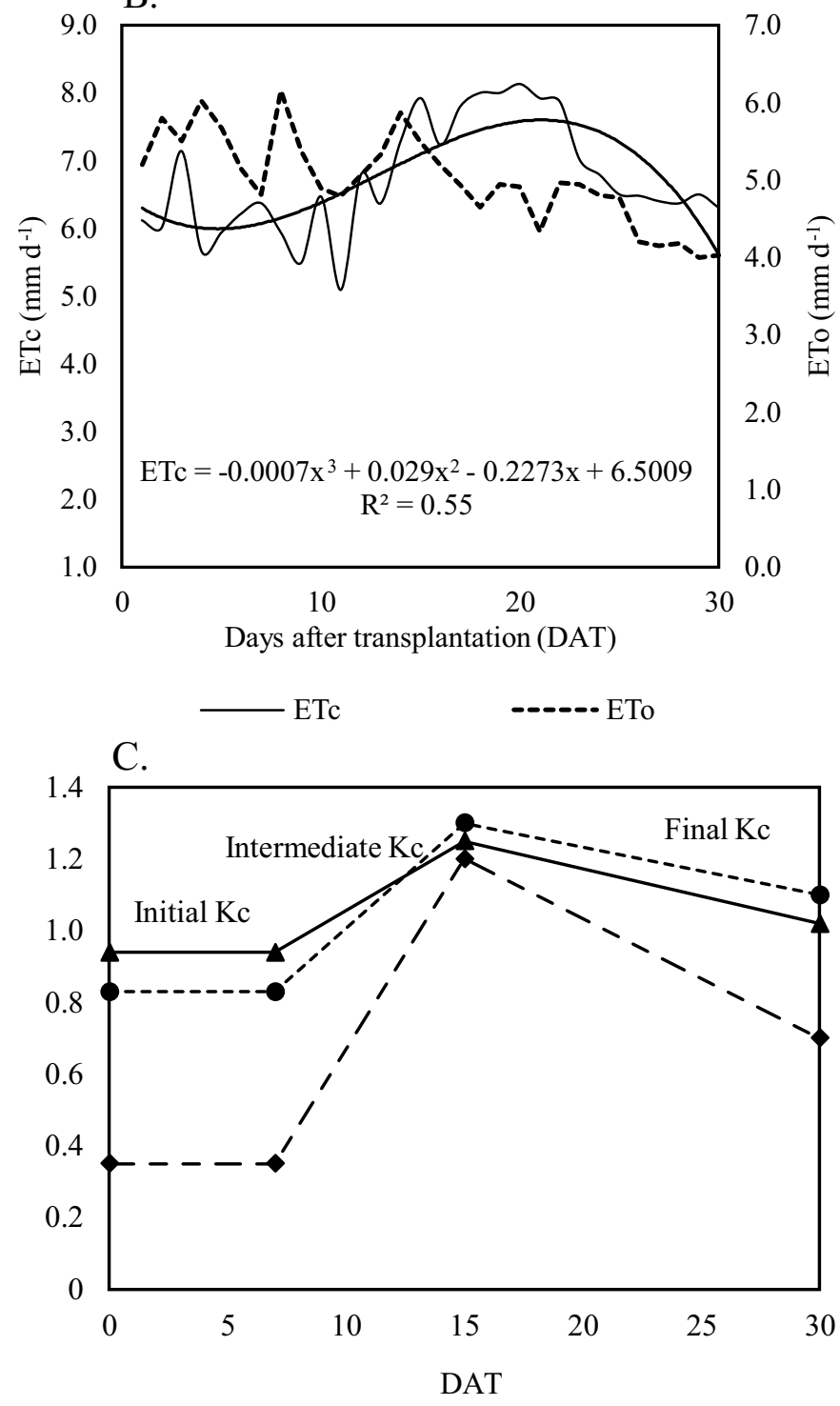

$\longrightarrow$ Kc Hargreaves-Samani ---- Kc Penman-Monteith

\section{$\longrightarrow \bullet-\mathrm{Kc}$ FAO-56}

Figure 3. Analysis of correlation between ETC and ETo in lysimeters, variation of the ETC temporal series and ETo and crop coefficient $(\mathrm{Kc})$
Similar results, corroborating the study, for the HargreavesSamani method were obtained by Guedes Filho et al. (2011); Fanaya Júnior et al. (2012) and Moura et al. (2013), who obtained "Optimal" performance, with $\mathrm{r}=0.99,0.87$ and 0.93 in studies conducted in Areia-PB (Agreste region), AquidauanaMS (Semi-arid region) and Vitória de Santo Antão-PE (Zona da Mata), respectively.

The Hargreaves-Samani method overestimated ETo, compared with the Penman-Monteith-FAO 56 method, showing value on the order of $4.81 \%$ (Figure $2 \mathrm{~B}$ ).

This overestimation observed in the method is probably related to the higher occurrence of rains recorded in April, which contributed to low temperatures, demonstrating the strong influence of maximum temperature on ETo estimation in this empirical method. This trend was also found by Borges \& Mediondo (2007), Back (2008) and Palaretti et al. (2014).

The daily correlations between ETc from the lysimeter and ETo from the Penman-Monteith-FAO 56 method were high, with coefficients of determination $\left(\mathrm{R}^{2}\right)$ of $0.9982\left(1^{\text {st }}\right.$ Stage), 0.9954 ( $2^{\text {nd }}$ Stage) and 0.9999 ( $3^{\text {rd }}$ Stage $)$, indicating high reliability of the data obtained in the drainage lysimeters (Figure 3A).

Until the first 15 DAT (Figure 3B), ETc remained lower than ETo because the leaf area of the crop was not yet fully developed. After 15 DAT, ETc became higher than ETo, evidencing that transpiration became preponderant over evaporation to compose the ETc.

From 24 DAT on, ETc decreased, which is justified by the beginning of the yellowing process or senescence of beet leaves, causing low ETc. ETc showed cumulative value of $202.11 \mathrm{~mm}$ along the studied period.

The mean Kc values of the beet crop estimated by PenmanMonteith-FAO 56 were 0.83 in the initial stage, 1.30 in the intermediate stage and 1.10 in the final stage. For HargreavesSamani, values corresponded to initial Kc of 0.94, intermediate $\mathrm{Kc}$ of 1.25 and final Kc of 1.02 (Figure 3C). Both Kc values estimated by the above-mentioned methods were compared with the mean values standardized by FAO-56, initial Kc of 0.35 , intermediate Kc of 1.20 and final Kc of 0.70 , respectively.

Compared with the standard FAO-56 method, Kc values of the beet crop were overestimated by the Penman-MonteithFAO-56 and Hargreaves-Samani methods. Similarly, Silva et al. (2015), also using lysimeters, found high Kc values in comparison to the standard FAO-56 method.

\section{Conclusions}

1. The Hargreaves-Samani method showed optimal performance index for evapotranspiration estimation compared with the standard FAO-56 method, indicating an excellent result for the study area.

2. Beet ETc showed a cumulative demand of $202.11 \mathrm{~mm}$, for a cumulative reference evapotranspiration of $152.00 \mathrm{~mm}$.

3. Kc values determined using the Penman-Monteith-FAO 56 and Hargreaves-Samani methods were overestimated, compared with Kc values of the standard FAO-56 method.

4. With the obtained results, it is possible to correct the equations of the methods for the region, allowing for adequate irrigation management. 


\section{Literature Cited}

Aboukaled, A.; Alfaro, A.; Smith, M. Lysimeters. Rome: FAO, 1982. 68p. Irrigation and Drainage Paper, 39

Allen, R. G.; Pereira, L. S.; Raes, D.; Smith, M. Crop evapotranspiration: Guidelines for computing crop water requirements. Rome: FAO, 1998. 300p. Irrigation and Drainage Paper, 56

Back, A. J. Desempenho de métodos empíricos baseados na temperatura do ar para a estimativa da evapotranspiração de referência em Urussanga. Irriga, v.13, p.449-466, 2008.

Borges, A. C.; Mediondo, E. M. Comparação entre equações empíricas para estimativa da evapotranspiração de referência na bacia do Rio Jacupiranga. Revista Brasileira de Engenharia Agrícola e Ambiental, v.11, p.299-300, 2007. https://doi.org/10.1590/S141543662007000300008

Borges Júnior, J. C. F.; Anjos, R. J.; Silva, T. J. A.; Lima, J. R. S.; Andrade, C. L. T. Métodos de estimativa da evapotranspiração de referência diária para a microrregião de Garanhuns, PE. Revista Brasileira de Engenharia Agrícola e Ambiental, v.16, p.380- 390, 2012. https:// doi.org/10.1590/S1415-43662012000400008

Camargo, A. P.; Sentelhas, P. C. Avaliação do desempenho de diferentes métodos de estimativa da evapotranspiração potencial no estado de São Paulo, Brasil. Revista Brasileira de Agrometeorologia, v.5, p.89-97, 1997.

Cavalcante Júnior, E. G.; Almeida, B. M. de; Oliveira, A. D. de; Espínola Sobrinho, J.; Araújo, E. M. de.; Vieira, R. Y. M. Estimativa da evapotranspiração de referência para a cidade de Mossoró- RN. Revista Brasileira de Agricultura Irrigada, v.4, p.87-92, 2010. https://doi.org/10.7127/rbai.v4n200110

Doorenbos, J.; Pruitt, W. O. Guidelines for predicting crop water requirements. Rome: FAO, 1977. 179p. Irrigation and Drainage Paper, 24

EMBRAPA - Empresa Brasileira de Pesquisa Agropecuária. Sistema brasileiro de classificação de solos. 2.ed. Rio de Janeiro: 2006. 306p.

EMBRAPA - Empresa Brasileira de Pesquisa Agropecuária. Zoneamento agroecológico do estado de Alagoas. Recife: Embrapa-Solos, 2013. 238p.

Fanaya Júnior, E. D.; Lopes, A. da S.; Oliveira, G. Q. de; Jung, L. H. Métodos empíricos para estimativa da evapotranspiração de referência para Aquidauana, MS. Revista Irriga, v.17, p.418-434, 2012. https://doi.org/10.15809/irriga.2012v17n4p418

Guedes Filho, D. H.; Santos Júnior, J. A.; Costa Filho, J. F. da; Francisco, P. R. M.; Campos, V. B. Estimativa da evapotranspiração de referência para a cidade de Areia, Paraíba. Revista Brasileira de Agricultura Irrigada, v.5, p.37-47, 2011. https://doi.org/10.7127/ rbai.v5n 100038

Köppen, W. Climatologia: Con un estudio de los climas de la tierra. México: Fondo de Cultura Econômica, 1948. 479p.

Lacerda, Z. C. de; Turco, J. E. P. Estimation methods of reference evapotranspiration (ETo) for Uberlândia - MG. Engenharia Agrícola, v.35, p.27-38, 2015. https://doi.org/10.1590/1809-4430Eng.Agric.v35n1p27-38/2015

Miranda, W. L.; Carvalho, L. G.; Castro Neto, P.; Santos, P. A. B. Utilização do lisímetro de drenagem para obtenção do "Kc" da mamoneira em plantio adensado. Revista Verde de Agroecologia e Desenvolvimento Sustentável, v.11, p.08-13, 2016.
Moura, A. R. C.; Montenegro, S. M. G. L.; Antonino, A. C. D.; Azevedo, J. R. G. de.; Silva, B. B. da.; Oliveira, L. M. M. de. Evapotranspiração de referência baseada em métodos empíricos em bacia experimental no estado de Pernambuco - Brasil. Revista Brasileira de Meteorologia, v.28, p.181-191, 2013. https://doi. org/10.1590/S0102-77862013000200007

Palaretti, L. F.; Mantovani, E. C.; Sediyama, G. C. Análise da sensibilidade dos componentes da equação de Hargreaves-Samani para a região de Bebedouro - SP. Engenharia Agrícola, v.29, p.299306, 2014. https://doi.org/10.1590/S0102-77862014000200012

Pereira, A. R.; Vila Nova, N. A.; Sediyama, G. C. Evapotranspiração. Piracicaba: Fundação de Estudos Agrários- Luiz de Queiroz FEALQ, 1997.183p.

Santana, M. J. de.; Ribeiro, A. A.; Mancin, C. A. Evapotranspiração e coeficientes de cultura para o alface e a rúcula cultivadas em Uberaba-MG. Revista Inova Ciência \& Tecnologia, v.2, p.7-13, 2016.

Santos, C. S. dos.; Santos, D. P. dos.; Oliveira, W. J. de.; Silva, P. F. da.; Santos, M. A. L. dos; Fontenele, A. J. P. B. Evapotranspiração de referência e coeficiente de cultivo da pimenteira no agreste alagoano. Revista Brasileira de Agricultura Irrigada, v.10, p.883892, 2016a. https://doi.org/10.7127/rbai.v10n500458

Santos, D. P. dos.; Santos, C. S. dos.; Silva, P. F. da.; Pinheiro, M. P. M. A.; Santos, J. C. Crescimento e fitomassa da beterraba sob irrigação suplementar com água de diferentes concentrações salinas. Revista Ceres, v.63, p.509-516,2016b. https://doi.org/10.1590/0034737X201663040011

Sediyama, M. A. N.; Santos, M. R.; Vidigal, S. M.; Salgado, L. T. Produtividade e exportação de nutrientes em beterraba cultivada com cobertura morta e adubação orgânica. Revista Brasileira de Engenharia Agrícola e Ambiental, v.15, p.883-889, 2011. https:// doi.org/10.1590/S1415-43662011000900002

Silva, A. O. da.; Silva, Ê. F. de F. e; Klar, A. E.; Cunha, A. R. da. Evapotranspiração e coeficiente de cultivo para a beterraba sob estresse salino em ambiente protegido. Irriga, v.19, p.375-389, 2014a. https://doi.org/10.15809/irriga.2014v19n3p375

Silva, E. M. P. da.; Andrade Júnior, A. S. de.; Bastos, E. A.; Viana, T. V. de A. Evapotranspiração e coeficiente de cultura da melancia em solo sob palhada e preparo convencional. Irriga, v.20, p.154164, 2015.

Silva, J. R. L. da; Montenegro, A. A. de A.; Santos, T. E. M. dos; Santos, E. S. dos. Desempenho de diferentes métodos de estimativa da evapotranspiração de referência para Fernando de Noronha. Irriga, v.19, p.390-404, 2014b. https://doi.org/10.15809/ irriga.2014v19n3p390

Tanaka, A. A.; Souza, A. P. de.;Klar, A. E.; Silva, A. C. da.; Gomes, A. W. A. Evapotranspiração de referência estimada por modelos simplificados para o Estado do Mato Grosso. Pesquisa Agropecuária Brasileira, v.51, p.91-104, 2016. https://doi. org/10.1590/S0100-204X2016000200001

Willmott, C. J.; Ckleson, S. G.; Davies, R. E.; Feddema, J. J.; Klink, K. M.; Legates, D. R.; O’Donnell, J.; Rowe, C. M. Statistics for evaluation and comparisons of models. Journal of Geophysical Research, v.90, p.8995-9005, 1985. https://doi.org/10.1029/JC090iC05p08995

Xavier, R. A.; Dornellas, P. da C. Análise do comportamento das chuvas no município de Arapiraca, região Agreste de Alagoas. Revista Geografia, v.14, p.49-64, 2010. 